\title{
BANK-SPECIFIC AND MACROECONOMIC DETERMINANTS OF NON- PERFORMING LOANS OF COMMERCIAL BANKS IN BANGLADESH
}

\author{
ASM Towhid ", Shinta Amalina Hazrati Havidz ${ }^{2}$, Mohammed Ameen Qasem Ahmed \\ Alnawah $^{3}$ \\ 1) Wuhan University of Technology, Wuhan, China. \\ 2) Finance Program, Accounting Department, Faculty of Economics \& Communication, Bina \\ Nusantara University. \\ ${ }^{3)}$ Wuhan University of Technology, Wuhan, China.
}

\begin{tabular}{|l|l|}
\hline ARTICLE INFORMATION & $\begin{array}{l}\text { Abstract: The prime objective of this research is to } \\
\text { Received : 27/09/2019 } \\
\text { identify the main determinants of non-performing } \\
\text { Issued : } 27 / 10 / 2019\end{array}$ \\
E-mail: asm towhid@whut.edu.cn \\
Mobile : +88 01612714423 \\
Bangladesh for the period 2011-2016 using panel \\
data modeling. This paper uses balanced panel data \\
method to examine both bank-specific (return on \\
average assets, net loans to deposit ratio, bank size, \\
cost-to-income ratio, and capital adequacy ratio) and \\
macroeconomic (real GDP growth rate and inflation \\
rate) variables. To attain the objectives, the present \\
research analyzed historical data and panel data \\
model using secondary data. To examine panel data \\
modeling, the researcher considers 16 private \\
commercial banks in Bangladesh and executed \\
pooled OLS model, fixed effect model, random effect \\
model and random effect with the robust standard \\
error. The researcher found a negative significant \\
relationship for return on average assets, net loans to \\
deposit ratio and inflation rate in relation to NPLs \\
and results are supporting the previous researcher. \\
Based on the findings, the study offers some valuable \\
strategies to the management to improve return on \\
average assets, net loans to deposit ratio and inflation \\
rate to reduce the NPLs at least under the tolerance \\
level. The study also delineates the limitations of this \\
work and direction for future research. \\
Keywords: Non-Performing Loans, Commercial \\
Bank, Macroeconomic Determinants, Bank-Specific \\
Determinants.
\end{tabular}




\section{INTRODUCTION}

Bank collect funds from the public by way of deposits and invested in the business by way of lending fund. A non-performing loan is defined as a non-performing asset in the banking sector which is not contributing to the income of the bank. It is also regarded as nonperforming assets.

As an intermediary financial institution, through the lending function of a bank needs to add value to the bank. This function comprises origination, funding, monitoring, and servicing of the loan. Loans are treated as assets of a bank. To maintain an asset to a standard quality various regulation has been issued by central bank such as provisioning requirement, write-off policy, loan classification criteria, income recognition, risk diversification, debt restructuring, directed lending etc.

Bangladesh strongly depends on the banking sector for a smooth and financial intermediation after the capital market. However, Bangladesh banking sector has been dispositioned for many years with the crisis of accumulation of huge non-performing loans. All types of banks, except Foreign Commercial Bank (FCBs), are facing the scare amount of bad loans. Since the 1980s, the central banks of the developing countries, following the pattern of the developed countries, have abided by the "prudential norms for asset classification", with a view to securing "transparency" and "quality" of the loan portfolios of the banks. It is a component of Financial Sector Reform Program (FSRP).

After the unveiling of unambiguous loan categorization system in 1989, loan classification system has submitted a number of changes from time to time. The present classification module is a little bit sit back compared to the international norms of classifying the loan. Almost a quarter of the total loans of the banking sector are now classified or nonperforming. The number of classified loans in the country's banks and financial organizations stood at Tk 63,435 crore in September last, Finance Minister AMA Muhith told at Parliament on $6^{\text {th }}$ February 2017 (UNB, 2017). According to Bangladesh Bank's statement, the number of classified loans in the banks was Tk 58,877 crore, which is 9.26 percent of the total bank loans in the country, till the period, he said replying to a starred question from Awami League MP Nasima Ferdusee (UNB, 2017). Although, the ratio was as $26.09 \%$ since in 1990 and high as $41.1 \%$ in 1999 and it came down gradually to the present level of $6.59 \%$. It is obvious that banks are losing profitability because of NPLs as banks cannot earn appropriate interest income from their classified loans. A bank with a high percentage of NPLs suffers from an erosion of the capital. All those adverse impacts of NPLs on banks financial health such as low profitability and low capital base are clearly reflected in Bangladesh banking sector (Parven, 2011).

The question arises as to why Bangladesh is not able to solve this problem for such a long time? A number of studies have been confronted to deal with the problem and to address this "default culture" phenomenon. Post-independence of Bangladesh, starting from the nationalization of banks has been well discussed about growth and convoy of high scale of non-performing loans by a number of authors (Islam and Moral, 1999).

Various steps have been taken to ascertain the non-performing loans problem with some theories relating to political economy backed by empirical findings. Islam et al., (1999) in their study on bank loan default accosted the idea of 'comprador government' and 'comprador bourgeoisie' developed by Paul Baran as an explanation of the behavior of Bangladeshi capitalist's class where trading, as opposed to manufacturing, becomes the main business of the 
capitalists and they act as importers, inventors, sales agents, suppliers, etc. Similar study also made an effort to explain the process of transfer of economic surplus through international trade based on Emmanuel's theory of 'unequal exchange' which complements Baran's explanation. Ahmad (1997) used three theoretical inflections in his findings for a sociopolitical explanation of the bank loan default problem of Bangladesh, the rational actor theory, the pluralist instrumentalist theory and the organizational bargaining theory. Based on researcher's recommendation some important factors as causes of loan default which comprise lack of willingness to pay coupled with diversion of fund, willful negligence and belief that waiver may be available in the future, operational problems, inability to utilize production capacity, power failure, improper credit appraisal, natural calamity, and unfair taxation. Nonprofessional handling of assets both by the NCBs and the private sector bank was reported as the main reasons for the accumulation of loan default problem in Bangladesh (Alam and Jahan, 1999). It included the Government directed credit for the loss-making public-sector enterprises and the private sector banksee lending to insiders and connected parties. Prof. Rehman Sobhan (1991) in his study on debt default problem examined the nature and problems relating to poor repayment status of the two DFIs-BSB and BSRS.

The researchers are interested to explain the present study in three ways for identifying the bank-specific and macroeconomic determinants of NPLs. First, we develop hypothesis using theoretical and empirical literature. In this section, a general brief description of literature review will be discussed consecutively bank-specific and macroeconomic determinants of NPLs. Then the determinants related literature will be summarized more specifically and precisely.

Second, the study will discuss the current NPLs situation in Bangladesh using statistical data. The demonstration of this section will be concise on the perception of economic and banking situation. This study will investigate that how are bad loans impacting in Bangladesh in the perception of the real economy and banking sector.

Finally, the paper will consider two individual factors namely bank-specific (illogical) and macroeconomic (logical). Researcher will identify the factors affecting on NPLs using panel data modeling process. In order to test the explanatory power of two new variables, as we motivated from the previous literature, will be introduced those are cost to income ratio (CIR) and capital adequacy ratio (CAR). Many studies and regulator has been considering the capital adequacy ratio as one of the main diverse of any financial institution's profitability (Bourke, 1989, Berger and Ofek, 1995, Thompson, Berker et al., 2002). The Cost Income ratio (CIR), with its limitations (Welch, 2006), another emerging determine of bank's efficiency. Mathuva (2009) examined capital adequacy ratio, cost income ratio and the performance of commercial banks in Kenya. The researcher found evidence that cost income ratio is inversely related to both bank profitability. This study also seeks to assess whether there is any relationship between bank efficiency and NPLs. Cost income ratio and capital adequacy ratio will be revealed bank's efficiency and stability of financial sector of the bank.

The leftover of the paper is arranged as follows. Section 2 a brief review of related literature. Moreover, hypothesis will be developed in this section. Section 3 provides an overview of the current situation of the NPLs in Bangladesh. Section 4 focuses on the econometric methodology that is applied for determining the factors affecting on NPLs. In section 5 discusses the results of econometric specifications. Finally, section 6 concludes. 


\section{LITERATURE REVIEW}

\section{A Brief Review Of Related Literature and Hypothesis Development}

In the majority of studies investigated the determinants of NPL either macroeconomic or bank-specific determinants. The exception includes Bercoff et al., (2002) who combine bankspecific and macroeconomic variables to explain the vulnerability of the Argentinean banking system over the 1993-1996 period. They strongly claim that non-performing loans are affected by both bank-specific factors and macroeconomic factors. Dimitrios et al.,(2016) those who identified the main determinants of non-performing loans in the Euro-area for the period 1990Q1-2015Q. Both bank and country-specific variables have examined in this research where they claimed macroeconomic variables such as unemployment and growth to exert a strong influence. Furthermore, as a shape future, NPLs; bank-specific variables related to management skills and risk preferences were found in this research. ROA and ROE were proxied as a managerial efficiency of a bank and loans to deposit ratio proxied as a risk preference. Sixteen central, Eastern and South-Eastern European nations were investigated by Klein (2013) and find both bank-specific as well as macroeconomic factors to influence NPLs. Makri et al. (2014) also, examined in 14 countries in the Eurozone, found both macroeconomic and bank-specific influence on NPLs. Messai and Jouini (2013) examine the role of both macroeconomic and bank-specific factors on NPLs in 85 banks in Italy, Greece, and Spain, respectively, for 20042008 and find unemployment rates, real interest rates, and poor credit quality to positively influence NPLs. Macit (2017) also found similar result both bank-specific and macroeconomic variables significantly influence NPLs. In this research also both bank-specific and macroeconomic variables will be assessed to determine the NPLs taking yearly data in a balanced panel. On the other hand, Salas and Saurina (2002) who synthesize macroeconomic and individual bank level variables to explain aggregate NPLs of Spanish Commercial and Savings Banks for the period 1985-1997. Their study revealed that real growth in GDP, rapid credit expansion, bank size, capital ratio and market power have variation in non-performing loans. This study shows that the total asset has a positive relationship with NPL.

Another researcher provoked the effect of bank-specific characteristics on NPLs. Podpiera and Weill (2008) found the relationship between efficiency and bad loans in the Czech banking industry from 1994 to 2005. Meanwhile, Berger and DeYoung (1997) investigated derived hypothesis for a sample of US commercial banks spanning the periods from 1985 to 1994 and enticement attention to the relation between bank-specific characteristics and emphasis on efficiency indicators and problem loans. Li et al.,(2007) argues that incentive contracts have a positive effect on managerial efforts to reduce NPLs in the Chinese banking system. Ewert et al.,(2000) investigate banks' lending performance in Germany and found high-interest rate and inadequate collateral had significant positive relationship between the banks indigent lending performance.

Most experiential studies examine the persuade of the macroeconomic environment on NPLs. Rinaldi and Sanchis-Arellano (2006) claim that disposable income, unemployment, and monetary conditions have a strong impact on NPLs for the household NPLs for a panel of European countries. Berge and Boye (2007) analyze, Nordic banking system over the period 1993-2005, that problem loans are highly sensitive to the real interest rates and unemployment. Boss et al., (2009) discovered the connectivity of credit risk of the main Austrian corporate sectors with the business cycle. Louzis et al.,(2012) examined macroeconomic variables (GDP, 
unemployment, interest rate, public debt) and management quality for the Greece banking system. They have proved that there is the real GDP growth rate, the unemployment rate, the lending rates and public debt have a strong association on the level of NPLs. Other researchers concentrate on the macroeconomic determinants of NPLs include Cifter et al. (2015), Segoviano et al.(2006) and Nkusu (2011). Viswanadham et al.,(2015) find in their study that economic condition and GDP impact significantly on the level of non-performing loans. Das and Ghosh (2007); Al-Smadi and Ahmad (2009); Warue (2013) and Brownbridge (1998) found a significant and negative relationship between problem loans and GDP. That indicates a fall back of economic activities increase NPLs. Fofack (2005) empirically analyzed the determinants motivating NPLs and found proof that economic growth, real exchange rate appreciation and the real interest rate lead to increase NPLs. Jimenez and Saurina (2006) also showed similar evidence, a positive relationship between market interest rate and problem loans. Warue (2013) also proved that lending interest rates are positive and significantly related to NPL in commercial banks. But Al-Smadi and Ahmad (2009) opposed the result, was found negatively significant, for the relationship between interest rate and credit risk of Jordanian banks. As to their explanation, low interest rate motivates economic activities and productivity that affect positively firms' earnings. Salas and Saurina (2002) discovered that real growth in GDP explains transformation in NPLs. Jimenez et al. (2005) revealed that NPLs are determined by high real interest rates and permissive credit terms in addition to GDP of the economy. Al-Smadi and Ahmad (2009) found that inflation causes a substantial negative impact on credit risk. Warue (2013) also concluded that inflation has a negative impact on government commercial banks. Empirical studies tend to confirm a positive and significant connection between the NPLs and unemployment rate of the economy.

The bank-specific factors include credit risk management (Ekanayake and Azeez, 2015, Unit, 2017), bank efficiency (Cifter, 2015), loan growth (Wang, 2007), market share (Beck, Jakubik et al., 2015), concentration of lending activities (Viswanadham and Nahid, 2015), bank's loan supervision capacity (Viswanadham and Nahid, 2015), reckless lending (Viswanadham and Nahid, 2015), fraud and dishonest (Viswanadham and Nahid, 2015), management deficiencies (Viswanadham and Nahid, 2015), poor credit documentation (Viswanadham and Nahid, 2015), non-use of prudent credit classification and risk assessment methods (Viswanadham and Nahid, 2015) concentration of lending activities (Viswanadham and Nahid, 2015), poor supervision capacity (Viswanadham and Nahid, 2015), and NPL rate of previous year (Ekanayake and Azeez, 2015).

Godlewski (2005) draw attention to the links between banks profitability and NPL. Return on assets (ROA) was used as a proxy for performance, shows banks profitability negatively impacts the level of NPL ratio. Das and Ghosh (2007) discover a strongly positive and a significant influence of credit growth on NPLs. Misra and Dhal's (2010) findings also are giving full support of Das and Ghosh's (2007) result. In this study, return on average assets (ROAA) reveals the managerial efficiency of banks. Good management should entail lowering NPLs (Dimitrios, Helen et al., 2016). It is the reason that the study develops the first hypothesis following below: 
1. $\mathbf{H}_{1}$ : ROAA has a negative association with NPL

$\mathrm{Hu}$ et al. (2006) highlighted risk profile of banks where greater credit-deposit ratio could have more NPLs. Though Dimitrios et al., (2016) expected net loans to deposit ratio have a positive influence on NPL but didn't get full support moral hazard hypothesis. In our research, we expect in the perception of Bangladesh that there might have negative relationship between net loans to deposit ratio (NLDEP) and NPL. Thus, the following hypothesis may be formulated:

2. $\mathbf{H}_{\mathbf{2}}$ : NLDEP has a negative association with NPL

States with the large-sized banking industry, banks may increase their leverage too much and extend loans to lower quality borrowers. In larger sized markets, banks often resort to excessive risk-taking since it is difficult to impose market discipline by regulators and banks expect government protection in the case of failures (see Stern and Feldman, 2004). Thus, NPLs may be positively impacted by the size. States like Florida or Georgia provide anecdotal evidence of this. Misra and Dhal (2010) findings are similar to that of Das and Ghosh (2007). They have discovered a positive relation with the size of the bank. According to their explanation, large banks are more likely to have relatively more NPAs, due to the balance sheet constraint. But $\mathrm{Hu}$ et al. (2004) found a negative relationship between bank size and NPLs. Their justification is that greater credit-deposit ratio could have more NPLs.

In this regard, our study motivated by diversification hypothesis. There might be any relation between banks' diversification opportunity and loan quality. Our study expects a negative relation between diversification and NPLs since diversification has low credit risk. Salas and Saurina (2002) used bank size as a proxy for diversification opportunities, found a negative relationship between bank size and NPLs and claim bigger size allows for more diversification opportunities. Thus, the following hypothesis may be formulated:

3. $\mathbf{H}_{3}$ : Size has a negative association with NPL

D. M. Mathuva (2009) uses capital adequacy ratio and cost income ratio to examine the performance of commercial banks in Kenyan for the period 1998 to 2007. In this study, Costto-income ratio (CIR) used to measure the bank's efficiency and was found that the CIR is inversely related to bank profitability measure. Though the Cost Income Ratio has some limitation Welch (2006) but it is another emerging measure of bank's efficiency and a benchmarking metric (Tripe, 1998, Hess and Francis, 2004). The CIR, is being a standard benchmark of bank's efficiency, measures a bank's operating costs as a proportion of its total (i.e., net interest and non-interest) (Welch, 2006). It seeks to establish whether lower CIR lead to lower NPLs and basis on this idea number $4^{\text {th }}$ hypothesis has developed. This is the new variable stemming from the theoretical literature in order to test its explanatory power. Thus, the following hypothesis may be formulated:

4. $\mathbf{H}_{4}$ : CIR has a positive association with NPL

D. M. Mathuva (2009) reviled that the bank profitability positively related to the core capital ratio and the tire 1 risk-based capital ratio. As like ROAA, capital adequacy ratio also unwraps bank's stability and efficiency. The stable and efficient management system in the financial department of bank will lead to lower NPLs. This is another new variable stemming from the theoretical literature in order to test its explanatory power. Thus, the following hypothesis may be formulated: 
5. $\mathbf{H}_{5}$ : CAR has a negative association with NPL

Inflation growth (Rajan and Dhal, 2003, Al-Smadi and Ahmad, 2009, Khemraj and Pasha, 2009), interest rate (De Lis, Pagés et al., 2001, Fofack, 2005, Jesus and Gabriel, 2006, Al-Smadi and Ahmad, 2009), real GDP growth, unemployment rate (Messai and Jouini, 2013), money multiplier, credit growth, and reserve adequacy (Bercoff, Giovanni et al., 2002) are the part of macroeconomic factors. Bank's performance is influencing by macroeconomic factors are viewed as exogenous forces.

GDP is a very emergent environmental condition that can alter the demand and supply of loans and deposits in the country (Bilal, Saeed et al., 2013). N.Viswanadham (2015) found that GDP has a negative significant influence on NPL. Das and Ghosh (2007); Al-Smadi and Ahmad (2009); Warue (2013) and Brownbridge (1998) discovered a significant and negative relationship between non-performing loans and GDP. Salas and Saurina (2002) revealed that real growth in GDP leads to rising NPLs. Skarica (2014) uses quarterly data from 2007-2012 for 7 Central and East European countries, to examine the macroeconomic determinants of NPLs, and the result is supporting the other researcher as the reveal there is a negative and significant relationship between real GDP growth and NPLs. Jakubik and Reininger (2013) observe the determinants of NPLs comprising 9 Central, Eastern and Southeastern European (CESEE) countries including of Bulgaria, Croatia, the Czech Republic, Hungary, Poland, Romania, Russia, Slovakia, and Ukraine. The researcher discovers real GDP growth and national stock price index lead to diminishing NPLs over 2004-2012 while a nation's exchange rate, private credit-to-GDP, and past NPLs to increase present period's NPLs. The real GDP growth is anticipated to have a negative effect of NPLs. Thus, the following hypothesis may be formulated:

6. $\mathbf{H}_{6}$ : RGDP has a negative association with NPL

Skarica (2014) uses quarterly data from 2007-2012 for 7 Central and East European countries, to examine the macroeconomic determinants of NPLs, and find both unemployment and inflation rates to rise the growth of NPLs. The inflation rate is peroxided by the percentage of the CPI and it is expected to have a negative impact on NPLs as the lower inflation rate can improve loan repayment. Thus, the following hypothesis may be formulated:

7. $\mathbf{H}_{7:}$ INF has a negative association on NPL

Based on these hypotheses a conceptual framework is given below (Picture 1):

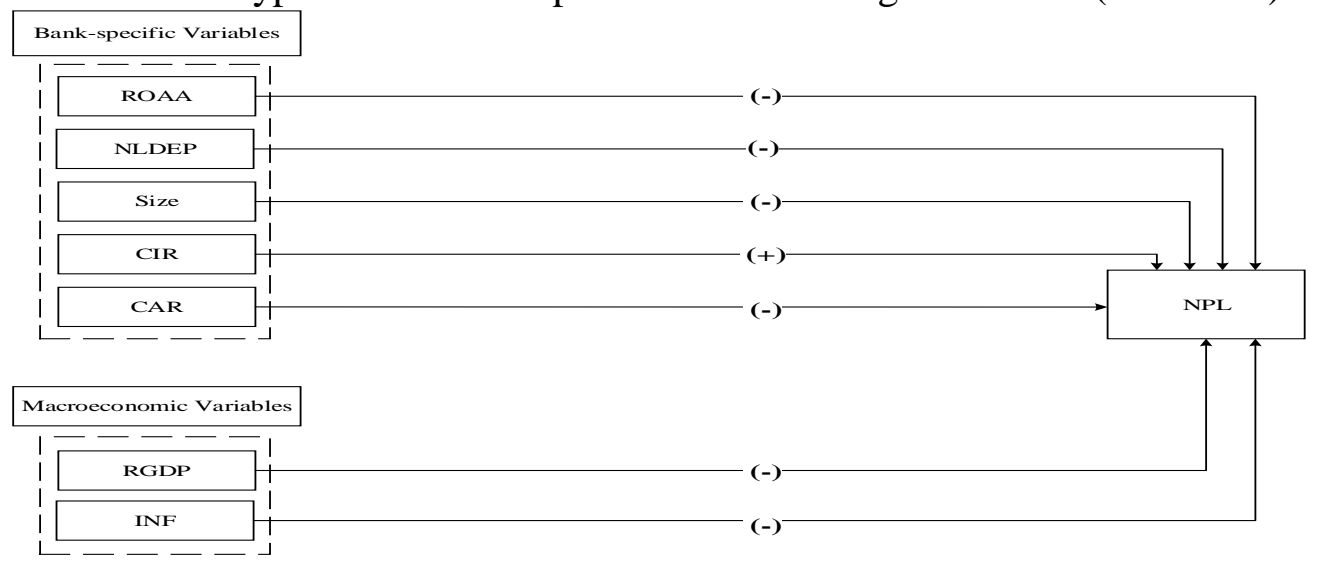

Picture 1 Conceptual Framework of Determinants of NPLs of Commercial Banks in Bangladesh (Source: Compiled by Visio 2016) 


\section{The Current Situation Of The Non-Performing Loans In Bangladesh}

Banking economic situation enormously depends on NPLs. A brief discussion of the bank's earning and profitability may bring the clear knowledge about the banking economic situation. The return on assets (ROA) is the most respective and widely used indicators of earnings and profitability though there are various indicators to measure. Return on assets is accompanied by a return on equity (ROE) and net interest margin (NIM) (Bangaldesh Bank, 2016).

Table 1 Profitability Ratio by Bank Type (Percent)

\begin{tabular}{llllllllllllllllllllll}
\hline Bank & \multicolumn{11}{c}{ Return on assets (ROA) } \\
\cline { 2 - 4 } & 2008 & 2009 & 2010 & 2011 & 2012 & 2013 & 2014 & 2015 & 2016 & 2008 & 2009 & 2010 & 2011 & 2012 & 2013 & 2014 & 2015 & 2016 \\
\hline SCBs & 0.7 & 1.0 & 1.1 & 1.3 & -0.6 & 0.6 & -0.6 & -0.04 & -0.2 & 22.5 & 26.2 & 18.4 & 19.7 & -11.9 & 10.9 & -13.6 & -1.5 & -9.5 \\
DFIs & -0.6 & 0.4 & 0.2 & 0.1 & 0.1 & -0.4 & -0.7 & -1.2 & -2.0 & -6.9 & -47.9 & -3.2 & -0.9 & -1.1 & 5.8 & -5.97 & -5.8 & -9.5 \\
PCBs & 1.4 & 1.6 & 2.1 & 1.6 & 0.9 & 1.0 & 1.0 & 1.0 & 0.7 & 16.4 & 21.0 & 20.9 & 15.7 & 10.2 & 9.8 & 10.3 & 10.8 & 9.4 \\
FCBs & 2.9 & 3.2 & 2.9 & 3.2 & 3.3 & 3.0 & 3.4 & 2.9 & 2.7 & 17.8 & 22.4 & 17.0 & 16.6 & 17.3 & 16.9 & 17.7 & 14.6 & 13.2 \\
Total & $\mathbf{1 . 2}$ & $\mathbf{1 . 4}$ & $\mathbf{1 . 8}$ & $\mathbf{1 . 5}$ & $\mathbf{0 . 6}$ & $\mathbf{0 . 9}$ & $\mathbf{0 . 6}$ & $\mathbf{0 . 8}$ & $\mathbf{0 . 4}$ & $\mathbf{1 5 . 6}$ & $\mathbf{2 1 . 7}$ & $\mathbf{2 1 . 0}$ & $\mathbf{1 7 . 0}$ & $\mathbf{8 . 2}$ & $\mathbf{1 1 . 0}$ & $\mathbf{8 . 1}$ & $\mathbf{1 0 . 5}$ & $\mathbf{7 . 1}$ \\
Source: Bangladesh Bank. & & & & & & & &
\end{tabular}

ROA and ROE are showing in Table 1 by four types of banks over the period 2008-2015. the analysis of this indicator reveals that ROA of SCBs (State-Owned Commercial Banks) and DFIs (State-Owned Development Financial Institutions) have not improved much because their ROA is less than the industry average. ROA of PCBs' (Private Commercial Banks) shows steadily strong position up to 2010 when it was decreasing trend during 2011-2012 due to declining net profit. After 2012 it is continuously increasing. In contrast to FCBs' (Foreign Commercial Banks) ROA had been consistently strong during the last couple of year.

The percentage ROE of SCBs was fluctuating from 2008 to 2011 but it's becoming negating figure from 2012. Since 2012 it was reduced even under zero though improved on 2013 compared to 2012. ROE of the DFIs was also negative figure. Though ROE of PCBs slightly increased to 10.8 percent in 2015 from 10.3 percent in 2014 and again it decreased to 9.4 percent in 2016. ROE of FCBs declined continuously to 14.6 and 13.2 percent in 2015 and 2016 respectively.

Table 2 NPL Ratios by Type of Banks

\begin{tabular}{llllllllll}
\hline Bank types & 2008 & 2009 & 2010 & 2011 & 2012 & 2013 & 2014 & 2015 & $\begin{array}{c}2016 \\
\text { June }\end{array}$ \\
\hline SCBs & 25.4 & 21.4 & 15.7 & 11.3 & 23.9 & 19.8 & 22.2 & 21.5 & 25.7 \\
DFIs & 25.5 & 25.9 & 24.2 & 24.6 & 26.8 & 26.8 & 32.8 & 23.2 & 26.1 \\
PCBs & 4.4 & 3.9 & 3.2 & 2.9 & 4.6 & 4.5 & 4.9 & 4.9 & 5.4 \\
FCBs & 1.9 & 2.3 & 3.0 & 3.0 & 3.5 & 5.5 & 7.3 & 7.8 & 8.3 \\
Total & $\mathbf{1 0 . 8}$ & $\mathbf{9 . 2}$ & $\mathbf{7 . 3}$ & $\mathbf{6 . 1}$ & $\mathbf{1 0 . 0}$ & $\mathbf{8 . 9}$ & $\mathbf{1 0 . 0}$ & $\mathbf{8 . 8}$ & $\mathbf{1 0 . 1}$ \\
\hline
\end{tabular}

Source: Bangladesh Bank

We suspect there might a negative relationship between ROA and NPLs vis-à-vis ROE and NPLs. Although, in this research, the researcher will analysis average ROA through regression analysis. Table 2 shows the NPLs ratio of the four types of banks from 2008 to 2016. The ratio of NPLs of the SCBs decreased from 25.4 percent in 2008 to 24.5 percent in 2015. The ratio of NPLs of the PCBs increased by 4.5 percent to 4.9 percent in 2014 and 5.4 percent in 2008 while 
those of the DFIs decreased to 23.2 percent in 2015 from 25.5 percent in 2008. The amount of NPLs of the FCBs increased from Taka 2.9 billion in 2008 to Taka 18.2 billion in 2015.The amount of NPLs of SCBs, DFIs, PCBs, and FCBs stood at 25.7; 26.1; 5.4 and 8.3 percent respectively at the end of June 2016.

During the liberation war in 1971, Bangladesh banking sector consists of only eleven banks, including two state-owned specialized banks, six nationalized commercialized banks and three Foreign Banks. Since 1980s banking industry was expanding when the private commercial bank was allowed to operate. At Present, two types of banks are operating in Bangladesh: Scheduled Banks: Those banks are operating under Bank Company Act, 1991 (Amended up to 2013). (ii) Non-Scheduled Banks: Those banks established for the particular purpose and they will not be allowed to perform as the scheduled bank can do.

Table 3 Banking Scenario of Bangladesh

\begin{tabular}{ccccccccc}
\hline Year & $\begin{array}{c}\text { Number } \\
\text { of Banks }\end{array}$ & $\begin{array}{c}\text { Percentage } \\
\text { Change of } \\
\text { Number of } \\
\text { Banks }\end{array}$ & $\begin{array}{c}\text { Number } \\
\text { of } \\
\text { Branches }\end{array}$ & $\begin{array}{c}\text { Percentage } \\
\text { Change of } \\
\text { Number } \\
\text { of } \\
\text { Branches }^{1}\end{array}$ & $\begin{array}{c}\text { Total } \\
\text { Assets } \\
\text { (in } \\
\text { Billion } \\
\text { Taka) }\end{array}$ & $\begin{array}{c}\text { Percentage } \\
\text { Change of } \\
\text { Total } \\
\text { Assets }\end{array}$ & $\begin{array}{c}\text { Deposits } \\
\text { (in } \\
\text { Billion } \\
\text { Taka) }\end{array}$ & $\begin{array}{c}\text { Percentage } \\
\text { Change of } \\
\text { Deposits }\end{array}$ \\
\hline 2000 & 51 & 0.00 & 6175 & 0.00 & 1098.15 & 0.00 & 827.19 & 0.00 \\
2001 & 50 & 1.96 & 6271 & 1.55 & 1280.31 & 16.59 & 956.28 & 15.61 \\
2002 & 49 & 3.92 & 6236 & 0.99 & 1453.06 & 32.32 & 1023.53 & 23.74 \\
2003 & 49 & 3.92 & 6253 & 1.26 & 1514.0 & 37.87 & 1140.3 & 37.85 \\
2004 & 49 & 3.92 & 6303 & 2.07 & 1725.5 & 57.13 & 1326.1 & 60.31 \\
2005 & 48 & 5.88 & 6412 & 3.84 & 2042.8 & 86.02 & 1554.7 & 87.95 \\
2006 & 48 & 5.88 & 6562 & 6.27 & 2406.7 & 119.16 & 1860.6 & 124.93 \\
2007 & 48 & 5.88 & 6717 & 8.78 & 2773.9 & 152.60 & 2148.9 & 159.78 \\
2008 & 48 & 5.88 & 6886 & 11.51 & 3313.5 & 201.73 & 2561.4 & 209.65 \\
2009 & 48 & 5.88 & 7095 & 14.90 & 3965.80 & 261.13 & 3037.60 & 267.22 \\
2010 & 47 & 7.84 & 7246 & 17.34 & 4411.98 & 301.76 & 3329.08 & 302.46 \\
2011 & 47 & 7.84 & 7961 & 28.92 & 5867.60 & 434.32 & 4509.70 & 445.18 \\
2012 & 47 & 7.84 & 8322 & 34.77 & 7030.70 & 540.23 & 5396.00 & 552.33 \\
2013 & 55 & 7.84 & 8685 & 40.65 & 8000.2 & 628.52 & 6273 & 658.35 \\
2014 & 56 & 9.80 & 9040 & 46.40 & 9143 & 732.58 & 6965.1 & 742.02 \\
2015 & 56 & 9.80 & 9397 & 52.18 & $10,314.6$ & 839.27 & 7928.6 & 858.50
\end{tabular}

Source: Annual Reports 2001-2015, Bangladesh Bank (BB).

Under central bank of Bangladesh's supervision, as per Bangladesh Bank Order, 1972 and Bank Company Act, 1991, there were 56 scheduled banks on 31 December. The banking sector in Bangladesh comprises four categories of scheduled banks-: State Owned Commercial Banks (SCBs), Specialized Development Banks (SDBs), Private Commercial Banks (PCBs) and Foreign Commercial Banks (FCBs). Currently, there are 4 SCBs which are wholly owned by the Government of Bangladesh while another 4 SDBs established to serve the specific objectives, such as the agricultural and industrial development. These banks are majorly owned by the 
Government of Bangladesh. PCBs includes 39 majorly owned by the shareholders and institutional owners. PCBs are further classified into two subgroups: 31 conventional PCBs that bank's all transaction based on interest rate and 8 Islamic Shariah-based PCBs where transactions related to profit-loss sharing policy. FCBs is comprised of 9 banks which work as the branches of international banks. All around Bangladesh, there were 56 scheduled banks had 9397 branches until 31 December 2015.

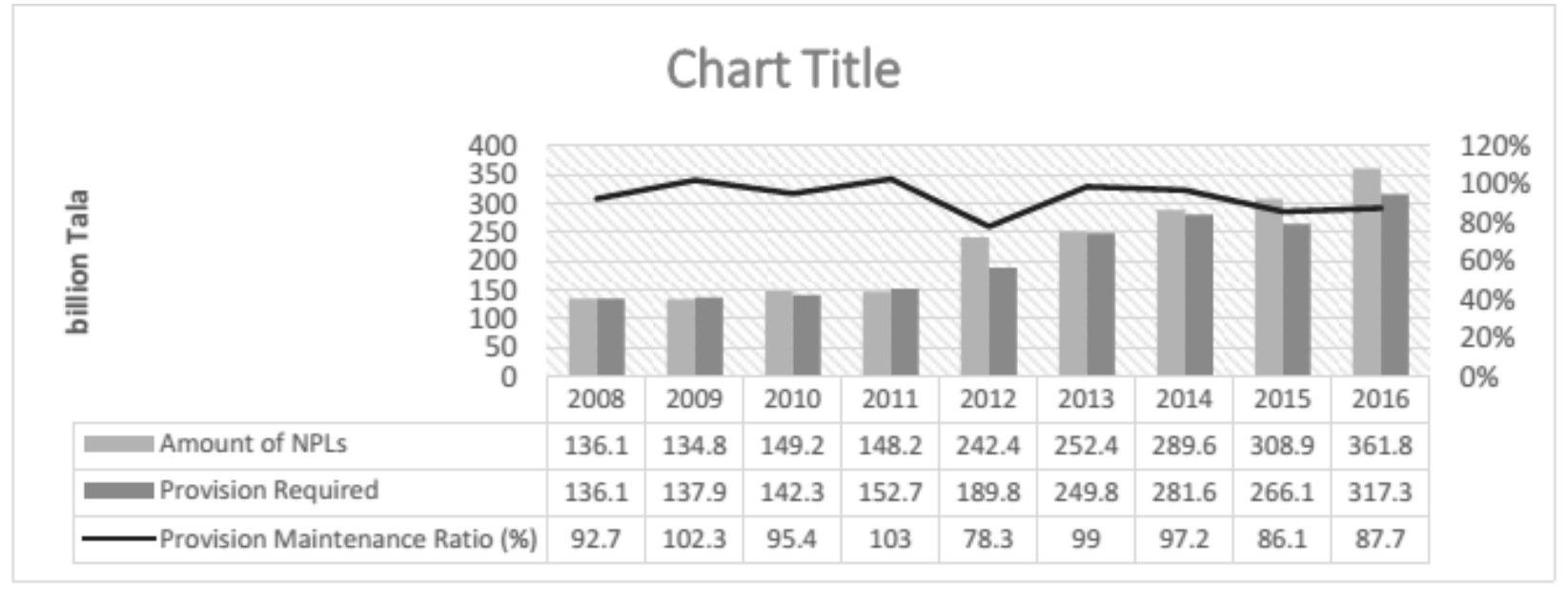

Picture 2 Provision adequacy position (Source: Bangladesh Bank, Annual Report 2015-2016)

Amongst 30 banks are listed while 26 banks are non-listed. Furthermore, there are three co-operative banks and one micro-finance bank (Grameen Bank) functioning in Bangladesh. Table 3 shows that the overall assets of banking industry amounted to BDT (the local currency of Bangladesh) 10,314.6 billion while the percentage of total assets 839.27 in 2015. Consequently, the deposits arose by 858.50 percent from 2000, and the overall deposits in 2015 shows BDT 7928.6 billion.

Error! Reference source not found. shows the amount of NPLs, provision required and provision-maintained ratio. In 2005 the amount of NPLs was taka 594.1 billion which increase to 633.7 billion in 2016. In the meantime, the amount of provision required was 266.1 and 317.3 billion in 2015 and 2016 respectively. Meanwhile, the ratio of provision maintain was 86.1 percent and 87.7 percent for the same years 2015 and 2016 respectively. From the above figure it can summarize that every year NPLs is increasing though from 2012 to 2016 the rate of increasing was very high. And maintained provision is lower than required provision as always.

\section{RESEARCH METHODS}

The research approach will be assessed for various factors and possibilities to ascertain a banking sector in Bangladesh and also the consequences for a commercial bank in case of nonperforming factors to be estimated. Analyzing the statistical facts and compare data among (factor wise) 2011-2016 in order to evaluate NPLs in 16 private commercial banks of Bangladesh.

On the other hand, observe the data time series analysis year to year and to investigate the data escalation for the definite years. This study will be analyzed through qualitative research since analyzing annual report exist in Bangladesh Bank (Central Bank of Bangladesh) and individual respective bank, Orbis bank data and world bank database. According to Aliaga and 
Gunderson (2000), quantitative research consists of explanation, data collection and analysis using mathematically based methods (in particular statistics) (Muijs, 2010). The empirical study is an evidence to draw the conclusion observing by collected information. Quantitative research describes variables, examine the relationship between variables, and determine the cause and effect reciprocations between variables (Burns and Grove, 1993).

\section{FINDINGS AND DISCUSSION}

\section{Empirical Results}

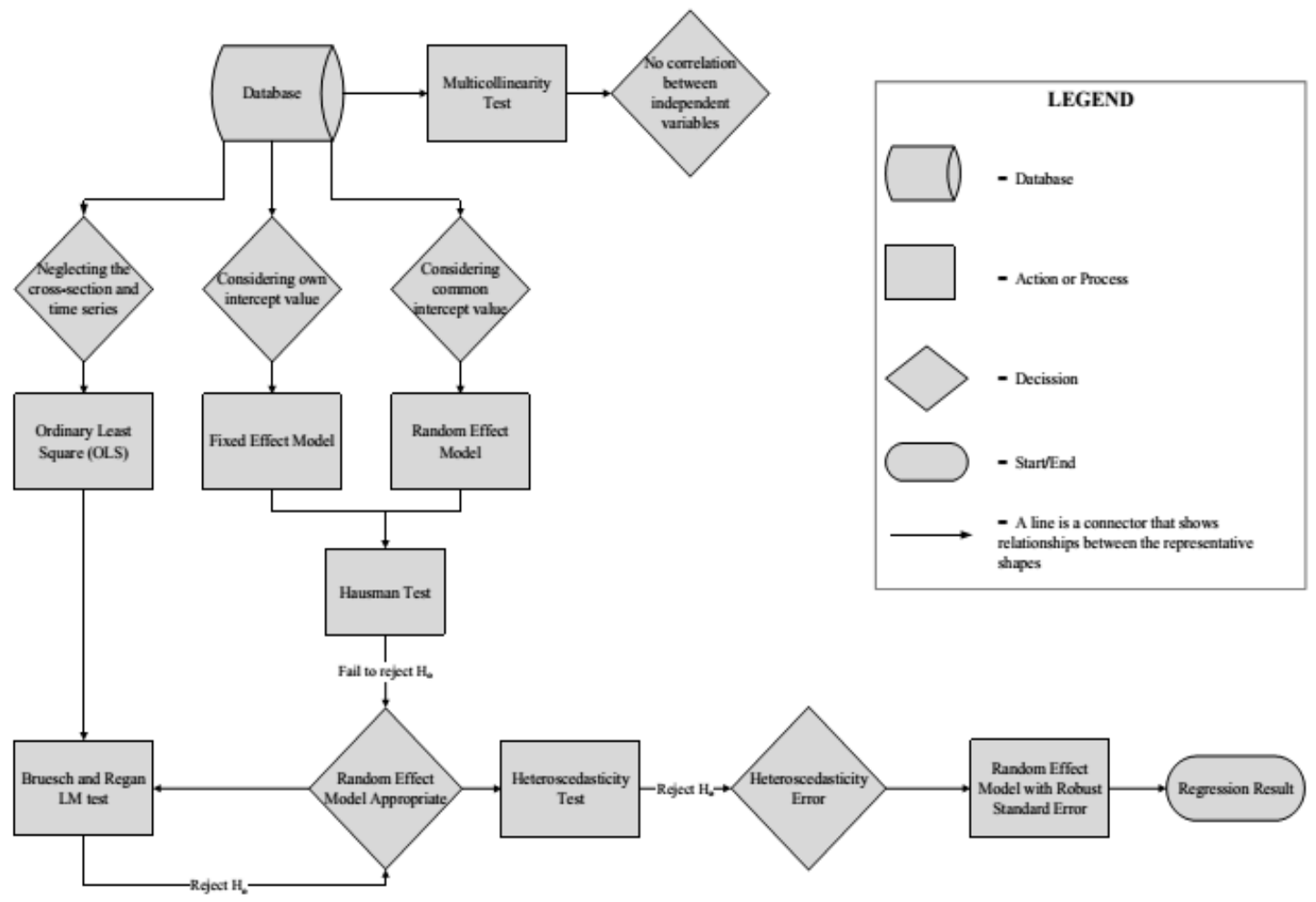

Picture 3 Panel Data Modeling Process (Source: Compiled by Visio 2016)

On the panel data modeling stage (see Picture 3), as we didn't find any multicollinearity problem then pooled OLS model (See Error! Reference source not found.) is estimated while neglecting cross-section and time series. Consequently, fixed effect model assessed (See Error! Reference source not found.).

Table 5 Determinants of Non-Performing Loans (Random Effects Estimation with Robust Standard Error) (Source: Compiled by Stata V14)

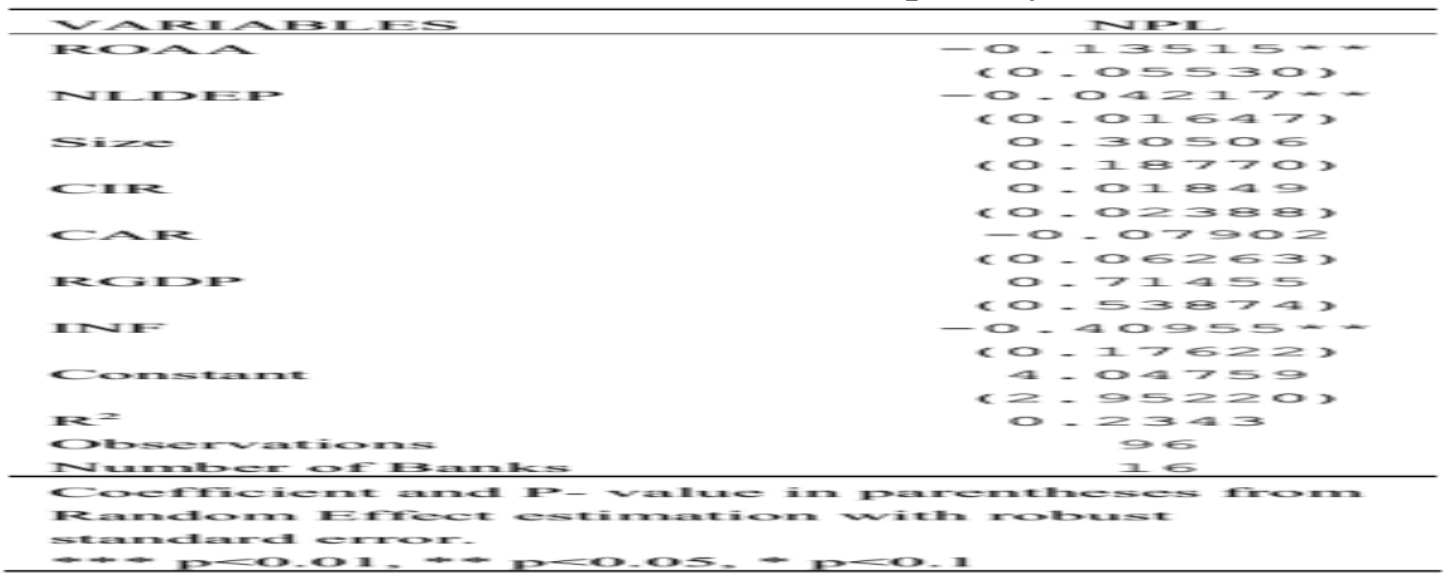




\section{Discussion}

In order to measure the effect of each independent variable partially to a dependent variable should be measured by z-test. Error! Reference source not found. 5 shows the estimation results of our model, where the co-efficient of the instructive variables and their standard error, and clustered z-statistics are stated. As the regression result shows the constant value 4.04759; means that the dependent variable, NPL will be 4.04759 when all independent variables will be zero. However, there are independent variables that have significant effects and proper sign, those are ROAA, NLDEP, and INF. The z-statistics value of ROAA and NLDEP are -2.44 and -2.56 respectively. This means that an improvement in ROAA and NLDEP are expected to see an instant reduction in NPLs. Dimitrios et al.,(2016) also found the same results in Euro-area and even the results corroborates other previous researchers. Meanwhile, Z-statistics of inflation rate is -2.32 while probability is 0.020 which lower than at 0.05 significant level. This indicates that the increasing of inflation rate may translate immediately into lower NPLs. On the other hand, the result is supporting the previous researcher those who proved that economic condition has a negative relationship with NPLs . Therefore, first $\left(\mathrm{H}_{1}\right)$, second $\left(\mathrm{H}_{2}\right)$ and seventh $\left(\mathrm{H}_{7}\right)$ hypothesis are failed to reject. It is supporting previous researcher (Louzis, Vouldis et al., 2012).

\section{CONCLUSIONS AND RECOMMENDATIONS}

The economic environment of Bangladesh is strongly depending on the banking sector for a smooth and financial intermediation while banking sector has been suffering the scare amount of bad loans. Every year government has to provide subsidy those banks' economic condition is being to be poor.

In order to find out the key determinants of non-performing loans of commercial banks in Bangladesh for the period 2011-2016, this study used panel data modeling process. The investigation revealed that return on average assets and net loans to deposit ratio have a negative significant effect on non-performing loans. Meanwhile, the inflation rate is found also a negative and statistically significant effect on non-performing loans.

The main purpose of this research is to identify determinants of non-performing loans of commercial banks in Bangladesh and to examine an empirical analysis to have a brief knowledge about the current situation of NPLs in Bangladesh with respect of real economy, investment efficiency and banking situation. Thus, the following recommendation are attributed:

1. The NPLs can be reduced to a great extent by improving return on average assets and net loans-to-deposit ratio. In this regard, the bank should strengthen the management efficiency. In order to improve the management efficiency banks may develop early warning indicator (EWI) based on different criteria. A graphical representation of EWI is given below:

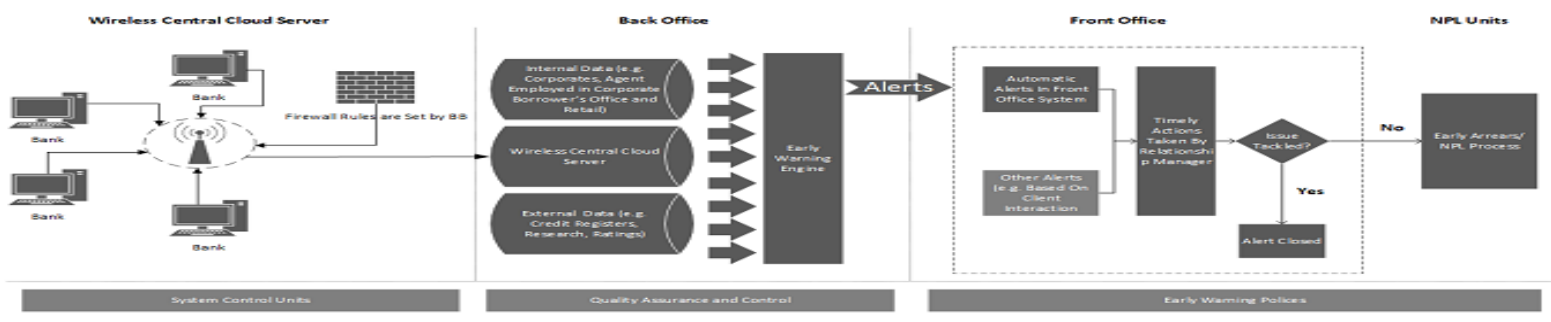

Picture 4 Early Warning Approach 
Picture 4 Shows a basic early warning process including the different phases and parties involved:

- Central cloud computing system owned by the Bangladesh Bank;

○ Quality assurance and control system owned by the back office;

O Early warning alert handling by the front office;

- Potential hand-over to NPL units in the case of deteriorating credit quality;

$\circ$ Quality assurance and control via second and third lines of defense.

Each of the following steps describes each section where it is very important to ensure the clear owner of the respective section. Furthermore, essential indicator, report and escalation procedure should be developed to ensure a pragmatic system that becomes able to protect the NPLs.

2. As we suggested in recommendation that Bangladesh Bank may develop a software which will be integrated with all bank ${ }^{\text {ee }} \mathrm{s}$ individual software in order to exchange interbank shareable data and to monitor the banks. In these regards ,wireless central cloud server"e has developed where strong reliable firewall rules will be designed by BB so that all banks can be monitored from very close and required data could able to share. In the second phase, back office will able to source data from three different sources such as internal data, wireless central cloud server, and external data. Then early warning engine will analyze the data set and will prepare for the next steps. The third phase, an automatic alert will be delivered from the alert engine and relationship manager will be a commanded to take necessary steps. In the front office section, the relationship officer will try to solve the if failed the alert will be forwarded to the NPLs unit otherwise alert will be closed.

3. BB should make a policy to stop borrowers who are maintaining with more than one bank and that borrowers are trying to disburse loan from different banks. This tendency may cause loan default. BB can develop an information system that is integrated with the information system of all other banks. As a result, BB can access the data of that individual borrower regarding his transaction history or any bad reputation about borrowing loan. At the same time, other banks can access BB's integrated information system to know about the bad debtors. So, the banks will only approve loans upon checking the sound credibility of the borrower. This idea can be developed from cloud computing system.

4. Bank may employ an agent in the borrower's company, especially in case of large corporate borrowers, who will be responsible for monitoring accounts section whether the lending amount is properly being used for the approved project as well or not. In this way, banks will be capable to monitor the borrowers on regular basis and closely after disbursement and they may give early warning if the businesses are going worse and they can give suggestion to the borrowers.

The current research evaluated the existing research on NPLs or NPA and developed an alternative method to estimate the determinants of non-performing loans. The review of the literature and new developed panel data model could enable a new way for the further research. The regression analysis shows $\mathrm{r}$-squared $=0.1649$. It means the dependent variables were analyzed for this research, can predict only 16.49 percent of NPLs. So, the rest 83.51 percent can be analyzed in future research. In the context of Bangladesh, the most important variable ,lack of good governance ${ }^{e e}$ did not consider in this research. Researcher suspect from 
their present research, ,lack of good governance ee may have a massive influence on the NPLs. As the researcher did not include other bank ${ }^{e e}$ group, then further research can be enhanced by including another bank group specially SCBs while it has high NPLs ratio compare to other bank groups. On the other hand, the researcher applied many statistical techniques in details which were not described in details in previous research in order to examine hypothesis test. These new tools can open window for the future research. Indeed, the methodology of this research may be employed for any other country for the same field.

\section{REFERENCE}

Aḥmad, A. (1997). "Towards an Islamic Financial Market: A Study of Islamic Banking and Finance in Malaysia."

Al-Smadi, M. O. and N. H. Ahmad (2009). "Factors affecting banks' credit risk: Evidence from Jordan." Collage of Business, University Utara Malaysia, Malaysia.

Alam, N. and S. B. Jahan (1999). "Default culture in banking sector of Bangladesh." Bank Parikrama 24(1): 23-38.

Aliaga, M. and B. Gunderson (2000). "Introduction to Quantitative research." Doing Quantitative Research in Education with SPSS. Thousand Oaks, CA: Sage Publications: 1-11.

Bangaldesh Bank, C. B. o. B. (2016). "Annual Report." Retrieved January 10, 2018, from https://www.bb.org.bd/pub/annual/anreport/ar1516/index1516.php.

Bank, T. W. (2017). Retrieved January 01, 2018, from https://data.worldbank.org/topic/economy-and-growth?view=chart.

Beck, R., et al. (2015). "Key Determinants of Non-performing Loans: New Evidence from a Global Sample." Open Economies Review 26(3): 525-550.

Bercoff, J. J., et al. (2002). "Argentinean Banks, Credit Growth and the Tequila Crisis: A Duration Analysis." Unpublished Paper.

Berge, T. O. and K. G. Boye (2007). "An analysis of banks' problem loans." Norges Bank. Economic Bulletin 78(2): 65.

Berger, A. N. and R. DeYoung (1997). "Problem loans and cost efficiency in commercial banks." Journal of Banking \& Finance 21(6): 849-870.

Berger, P. G. and E. Ofek (1995). "Diversification's effect on firm value." Journal of financial economics 37(1): 39-65.

Bilal, M., et al. (2013). "Influence of bank specific and macroeconomic factors on profitability of commercial banks: A Case Study of Pakistan."

Boss, M., et al. (2009). "modeling credit risk through the Austrian business cycle: An update of the OeNb model." Financial Stability Report 17: 85-101.

Bourke, P. (1989). "Concentration and other determinants of bank profitability in Europe, North America and Australia." Journal of Banking \& Finance 13(1): 65-79.

Burns, N. and S. K. Grove (1993). "The practice of nursing research." Conduct, critique \& utilization 4.

Cifter, A. (2015). "Bank concentration and non-performing loans in Central and Eastern European countries." Journal of Business Economics and Management 16(1): 117-137.

Das, A. and S. Ghosh (2007). "Determinants of credit risk in Indian state-owned banks: An empirical investigation." 
De Lis, F., et al. (2001). "Credit growth, problem loans and credit risk provisioning in Spain." bis Papers 1: 331-353.

Dimitrios, A., et al. (2016). "Determinants of non-performing loans: Evidence from Euro-area countries." Finance Research Letters 18: 116-119.

Ekanayake, E. and A. A. Azeez (2015). "Determinants of Non-Performing Loans in Licensed Commercial Banks: Evidence from Sri Lanka." Asian Economic and Financial Review 5(6): 868.

European Central Bank, B. S. (2016). "Draft guidance to banks on non-performing loans."

Ewert, R., et al. (2000). "Determinants of bank lending performance in Germany."

Schmalenbach Business Review: ZFBF 52(4): 344.

Focus, O. B. (2017). World Banking Information Source. Online, Bureau Van Dijk.

Fofack, H. (2005). "Nonperforming loans in Sub-Saharan Africa: causal analysis and macroeconomic implications."

Godlewski, C. J. (2005). "Bank capital and credit risk taking in emerging market economies." Journal of Banking Regulation 6(2): 128-145.

Goodhart, M. C., et al. (2006). Default, credit growth, and asset prices, International Monetary Fund.

Hess, K. and G. Francis (2004). "Cost income ratio benchmarking in banking: a case study." Benchmarking: An International Journal 11(3): 303-319.

HU, J. L., et al. (2004). "Ownership and nonperforming loans: Evidence from Taiwan's banks." The Developing Economies 42(3): 405-420.

Islam, M. and L. Moral (1999). Bank loan default problem in bangladesh: A dialogue between borrowers and lenders. Keynote paper (seminar paper) presented at Bangladesh Institute of Bank Management, published in Bank Parikrama, May.

Jakubík, P. and T. Reininger (2013). "Determinants of nonperforming loans in Central, Eastern and Southeastern Europe." Focus on European Economic Integration 3: 48-66.

Jesus, S. and J. Gabriel (2006). "Credit cycles, credit risk, and prudential regulation."

Khemraj, T. and S. Pasha (2009). "The determinants of non-performing loans: an econometric case study of Guyana."

Klein, N. (2013). "Non-performing loans in CESEE: Determinants and impact on macroeconomic performance."

Li, H., et al. (2007). "Incentive contracts and bank performance." Economics of Transition 15(1): 109-124.

Louzis, D. P., et al. (2012). "Macroeconomic and bank-specific determinants of non-performing loans in Greece: A comparative study of mortgage, business and consumer loan portfolios." Journal of Banking \& Finance 36(4): 1012-1027.

Macit, F. (2017). "What determines the non-performing loans ratio: evidence from Turkish commercial banks." CEA Journal of Economics 7(1).

Makri, V., et al. (2014). "Determinants of non-performing loans: The case of Eurozone." Panoeconomicus 61(2): 193.

Mathuva, D. (2009). "Capital adequacy, cost income ratio and the performance of commercial banks: The Kenyan Scenario." The International journal of applied economics and Finance 3(2): $35-47$.

Messai, A. S. and F. Jouini (2013). "Micro and macro determinants of non-performing loans." International Journal of Economics and Financial Issues 3(4): 852. 
Misra, B. and S. Dhal (2010). "Pro-cyclical management of banks' non-performing loans by the Indian public sector banks." BIS Asian Research Papers.

Muijs, D. (2010). Doing quantitative research in education with SPSS, Sage.

Nkusu, M. (2011). "Nonperforming loans and macrofinancial vulnerabilities in advanced economies."

Parven, S. (2011). "Nonperforming loans of commercial banks in Bangladesh."

Podpiera, J. and L. Weill (2008). "Bad luck or bad management? Emerging banking market experience." Journal of Financial Stability 4(2): 135-148.

Rajan, R. and S. C. Dhal (2003). "Non-performing loans and terms of credit of public sector banks in India: An empirical assessment." Occasional Papers 24(3): 81-121.

Rinaldi, L. and A. Sanchis-Arellano (2006). "Household debt sustainability: what explains household non-performing loans? An empirical analysis."

Salas, V. and J. Saurina (2002). "Credit risk in two institutional regimes: Spanish commercial and savings banks." Journal of Financial Services Research 22(3): 203-224.

Škarica, B. (2014). "Determinants of non-performing loans in Central and Eastern European countries." Financial theory and practice 38(1): 37-59.

Sobhan, R. (1991). Debt default to the development finance institutions: the crisis of state sponsored entrepreneurship in Bangladesh, University Press.

Thompson, E., et al. (2002). "Turkish Bank Capital Adequacy-Too Little, Too Late." FitchRatings Special Report 1.

Tripe, D. (1998). Cost to income ratios in Australasian banking, Department of Finance, Banking and Property, College of Business, Massey University.

UNB (2017). "Classified loans in banks, financial insts Tk 63,435cr." The Independent, Newspaper. Retrieved NOV 01, 2017, from http://www.theindependentbd.com/printversion/details/79643.

Unit, T. E. I. (2017). "Bangladesh Banking Secotr Faces Challenges." Retrieved 2017-10-16, 2017, from http://www.eiu.com.

Viswanadham, N. and B. Nahid (2015). "Determinants of Non Performing Loans in Commercial Banks: A Study of NBC Bank Dodoma Tanzania." International Journal of Finance \& Banking Studies 4(1): 70.

Wang, B. (2007). "Non-Performing Loan Resolution in the Context of China's Transitional Economy."

Warue, B. N. (2013). "The effects of bank specific and macroeconomic factors on nonperforming loans in commercial banks in Kenya: A comparative panel data analysis." Advances in Management and Applied Economics 3(2): 135.

Welch, P. (2006). Rethinking bank efficiency: The failings of the cost-income efficiency ratio. 